\title{
Depth adaptation in Amphistegina: change in lamellar thickness
}

\author{
PAMELA HALLOCK AND HANS JØRGEN HANSEN
}

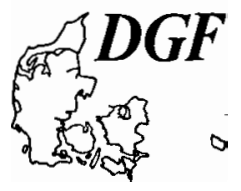

\begin{abstract}
Hallock, P. \& Hansen, H. J.: Depth adaptation in Amphistegina : change in lamellar thickness. Bull. geol. Soc. Denmark, vol 27, pp. 99-104, Copenhagen, March 23rd, 1979. https://doi.org/10.37570/bgsd-1978-27-10

Using specimens of Amphistegina lessonii, A. lobifera, and A.papillosa from the Gulf of Elat, changes in shell shape with depth observed in previous studies can be quantitatively accounted for by a corresponding trend in thickness of secondary laminae.
\end{abstract}

P. Hallock and H. J. Hainsen, Institute of Historical Geology and Palaeontology, Øster Voldgade 10, 1350 Kobenhavn K, Denmark, April 4th, 1978.

\section{Introduction}

In recent years, several authors have published observations regarding changes in test shape with depth in symbiont-bearing foraminifera (e.g. Hottinger and Dreher, 1974; Larsen, 1976; Hottinger, 1977; Larsen and Drooger, 1977). Using Amphistegina from the Gulf of Elat, Larsen and Drooger (op.cit.) demonstrated that the relationship between shell diameter and shell thickness changes through ontogeny at a given depth while for each size class the relationship shows a morphocline in populations from different depths. In Elat, the hydrographic conditions are unique since virtually no thermocline nor other cline exists in the water body (Klinker et al 1977); the only physical factor changing with depth is the amount and composition of light. This led Larsen (1976) to suggest that the increase in surface to volume with increasing depth observed in Amphistegina shells may be causally linked to the light gradient. In laboratory culture experiments, Hallock (in prep) found that Amphistegina grown at reduced light levels developed an increase in surface to volume ratio like that observed in nature by Larsen, indicating that the intraspecific variation in test shape is not genetic.

Hottinger (1977) reported on morphologic modifications in nummulitid shells with depth. He pointed out that in shallower environments, the shells are involute and thick, whereas they become evolute and thin in deeper waters. $\mathrm{He}$ further noted that there must be a relationship also to thickness of the secondary lamellae reflected by the solidity of the shell.

The above observations suggest that changes in surface to volume have structural implications within the foraminiferal shell. The purpose of this study was to determine if the depth associated trends in test shape are the result of corresponding trends in the thickness of the lamellae from which the test is constructed.

\section{Materials and methods}

Material used in this study originated from the same set of samples studied by Larsen (1976) and Larsen and Drooger (1977). Specimens to be examined for lamellarity were prepared according to the techniques already published in several articles (e.g. Hansen and Lykke-Andersen, 1976). The sections were studied and photographed in Cambridge MK.IIa and 180 scanning electron microscopes housed in the Geological Institute of the University of Copenhagen. They were coated with $200 \AA$ gold using a Polaron sputter device. Overlapping mosaics of enlargements of approximately $2000 x$ were prepared of the areas of interest. Thus, thicknesses of individual secondary lamellae could be measured to the nearest $0.25 \mu \mathrm{m}$. Secondary lamellae were measured in the umbilical regions of both the spiral and umbilical sides in vertical sections through the proloculus.

In preparations of the kind used in this study, 
the boundaries between secondary lamellae are generally distinct. However, in a few cases, measurements were difficult due to the existence of primary lamination (sensu Hansen et al 1969). The primary laminae are not continuous and cannot be followed. Therefore, when lamels were measured, the boundaries were traced not only on the high magnification photographs, but also on corresponding lower magnification pictures whereby primary laminae were identified.

\section{Observations}

The structure of the group of foraminifera usually contained in the family Asterigerinidae was described in some detail by Hansen and Reiss (1972). They demonstrated that members of this family basically follow an identical scheme regarding both morphology and structure. All members were found to construct their chambers of two layers of calcite separated by an organic layer. With the addition of a new chamber, the outer calcareous layer forms a continuous sheet of material covering all exposed ontogenetically younger shell parts. In addition, the new chamber is subdivided by a partitional wall constructed of the double inner calcareous layer with an additional inpush termed the "gutter constructed of the inner as well as the outer calcareous layer separated by the organic median layer.

The genus Amphistegina is separated from the genus Asterigerina and associated forms by the partly involute arrangement of the chambers on the spiral side. With the addition of new chambers and thereby deposition of secondary lamellae, the maximum number of secondary lamellae deposited on any chamber wall in the final whorl

Table 1.

\begin{tabular}{|c|c|c|c|c|c|c|c|c|}
\hline \multirow[t]{2}{*}{ Species } & \multirow{2}{*}{$\begin{array}{c}\text { Depth } \\
\text { (m) }\end{array}$} & \multirow{2}{*}{$\begin{array}{c}\bar{D} \\
(\mu \mathrm{m})\end{array}$} & \multirow[t]{2}{*}{$\bar{D} / T$} & \multirow{2}{*}{$\begin{array}{l}\text { Number } \\
\text { chambers }\end{array}$} & \multicolumn{2}{|c|}{$\begin{array}{l}\text { Lamellar } \\
\text { spiral }\end{array}$} & \multicolumn{2}{|c|}{$\begin{array}{c}\text { thickness }(\mu \mathrm{m}) \\
\text { umbilical }\end{array}$} \\
\hline & & & & & $x$ & SD & $x$ & SD \\
\hline A. lobifera & 5 & $\begin{array}{r}1000 \\
890 \\
1050\end{array}$ & $\begin{array}{l}1.57 \\
1.63 \\
1.79\end{array}$ & $\begin{array}{l}29 \\
22 \\
24\end{array}$ & $\begin{array}{l}7.3 \\
7.6 \\
7.6\end{array}$ & $\begin{array}{l}5.5 \\
6.1 \\
3.9\end{array}$ & $\begin{array}{r}10.5 \\
9.4 \\
11.5\end{array}$ & $\begin{array}{l}7.5 \\
7.5 \\
4.4\end{array}$ \\
\hline : & 45 & $\begin{array}{r}1100 \\
1250 \\
1244\end{array}$ & $\begin{array}{l}1.88 \\
1.96 \\
2.08\end{array}$ & $\begin{array}{l}37 \\
34 \\
29\end{array}$ & $\begin{array}{l}4.9 \\
6.0 \\
5.8\end{array}$ & $\begin{array}{l}3.0 \\
2.6 \\
2.5\end{array}$ & $\begin{array}{l}9.3 \\
9.0 \\
7.8\end{array}$ & $\begin{array}{l}5.0 \\
4.8 \\
4.0\end{array}$ \\
\hline A. lessonii & 5 & $\begin{array}{l}1165 \\
1148 \\
1174\end{array}$ & $\begin{array}{l}1.99 \\
2.07 \\
1.98\end{array}$ & $\begin{array}{l}36 \\
30 \\
40\end{array}$ & $\begin{array}{l}4.8 \\
6.1 \\
4.2\end{array}$ & $\begin{array}{l}2.1 \\
3.6 \\
1.8\end{array}$ & $\begin{array}{l}7.9 \\
9.1 \\
8.4\end{array}$ & $\begin{array}{l}2.8 \\
5.3 \\
3.8\end{array}$ \\
\hline & 38 & $\begin{array}{r}1056 \\
869 \\
1044\end{array}$ & $\begin{array}{l}2.29 \\
2.17 \\
2.23\end{array}$ & $\begin{array}{l}36 \\
30 \\
33\end{array}$ & $\begin{array}{l}4.2 \\
4.7 \\
4.5\end{array}$ & $\begin{array}{l}2.2 \\
2.5 \\
2.2\end{array}$ & $\begin{array}{l}6.7 \\
6.9 \\
7.0\end{array}$ & $\begin{array}{r}3.6 \\
-\quad 3.8 \\
3.9\end{array}$ \\
\hline & 64 & $\begin{array}{l}900 \\
929 \\
850\end{array}$ & $\begin{array}{l}2.24 \\
2.42 \\
2.41\end{array}$ & $\begin{array}{l}32 \\
29 \\
24\end{array}$ & $\begin{array}{l}3.3 \\
3.8 \\
4.5\end{array}$ & $\begin{array}{l}1.9 \\
2.2 \\
1.4\end{array}$ & $\begin{array}{l}6.4 \\
7.0 \\
5.7\end{array}$ & $\begin{array}{l}3.8 \\
3.9 \\
3.0\end{array}$ \\
\hline A. papillosa & 45 & $\begin{array}{r}958 \\
983 \\
1100\end{array}$ & $\begin{array}{l}2.56 \\
2.60 \\
2.27\end{array}$ & $\begin{array}{l}48 \\
42 \\
49\end{array}$ & $\begin{array}{l}3.3 \\
2.7 \\
3.6\end{array}$ & $\begin{array}{l}1.8 \\
1.6 \\
1.7\end{array}$ & $\begin{array}{l}3.3 \\
3.6 \\
3.8\end{array}$ & $\begin{array}{l}1.8 \\
1.9 \\
2.1\end{array}$ \\
\hline & 70 & $\begin{array}{l}980 \\
919 \\
960\end{array}$ & $\begin{array}{l}2.87 \\
3.12 \\
2.87\end{array}$ & $\begin{array}{l}44 \\
44 \\
37\end{array}$ & $\begin{array}{l}3.2 \\
1.9 \\
2.3\end{array}$ & $\begin{array}{l}1.5 \\
1.1 \\
1.0\end{array}$ & $\begin{array}{l}3.3 \\
3.0 \\
2.9\end{array}$ & $\begin{array}{l}1.8 \\
0.8 \\
1.2\end{array}$ \\
\hline$\cdot$ & 90 & $\begin{array}{l}939 \\
904 \\
905\end{array}$ & $\begin{array}{l}3.65 \\
4.37 \\
3.70\end{array}$ & $\begin{array}{l}49 \\
40 \\
43\end{array}$ & $\begin{array}{l}2.1 \\
1.3 \\
1.9\end{array}$ & $\begin{array}{l}1.1 \\
0.6 \\
1.1\end{array}$ & $\begin{array}{l}2.3 \\
2.0 \\
2.4\end{array}$ & $\begin{array}{l}1.0 \\
1.0 \\
1.1\end{array}$ \\
\hline - bicirculata & 45 & $\begin{array}{l}1350 \\
1140 \\
1357\end{array}$ & $\begin{array}{l}3.41 \\
2.78 \\
2.84\end{array}$ & $\begin{array}{l}33 \\
32 \\
39\end{array}$ & $\begin{array}{l}3.4 \\
3.9 \\
4.7\end{array}$ & $\begin{array}{l}1.6 \\
2.5 \\
2.2\end{array}$ & $\begin{array}{l}4.7 \\
5.6 \\
5.6\end{array}$ & $\begin{array}{l}2.2 \\
2.7 \\
2.3\end{array}$ \\
\hline
\end{tabular}

Table 1. Diameter $(\bar{D})$, shape index $(\bar{D} / T)$, number of chambers and mean lamellar thickness for four species of Amphistegina from the Gulf of Elat. 


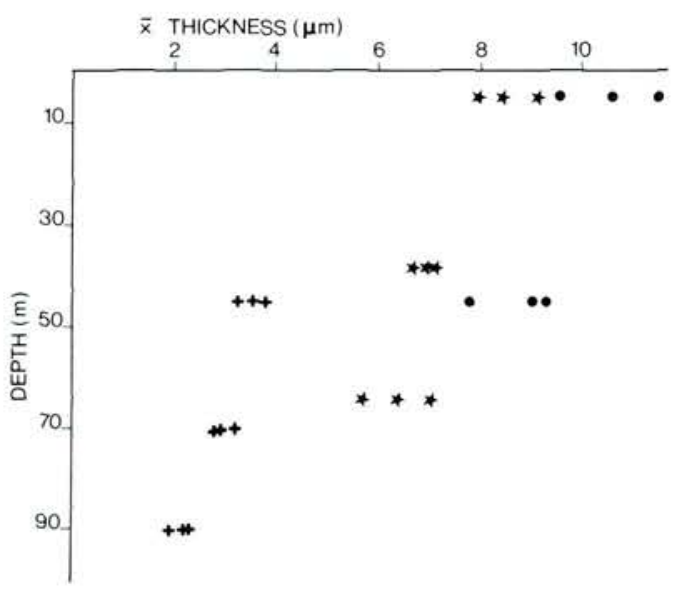

- A. lobifera

$\star$ A. lessonii

+ A. papillosa

Figure 1. Mean lamellar thickness of the umbilical side (umbilical region) versus depth for three species of Amphistegina.

corresponds to the number of chambers exposed. By contrast, the umbilical regions receive secondary lamellae from all chambers deposited through ontogeny since coiling is partially evolute. Accordingly, since test shape as defined in previous studies is expressed as shell diameter relative to shell thickness as measured from one

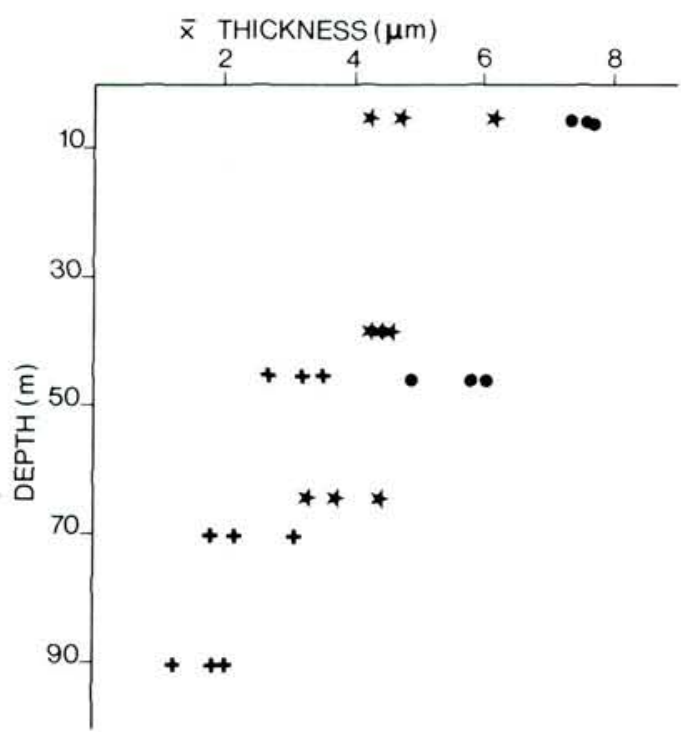

Figure 2. Mean lamellar thickness of the spiral side (umbilical region) versus depth for three species of Amphistegina. Legend like in Fig. 1. umbilicus to the other, any constant change in lamel thickness between individuals will have a cumulative effect on the measurements carried out in the umbilical region, but to a lesser degree in the diameter.

Since the techniques applied are rather time consuming, representative specimens were selected. Larsen and Drooger (1977) tabulated size-specific shape indices (ratio of diameter/thickness) with depth for a series of Amphistegina spp. from Elat. For the present study individuals of approximately median shape index from four depths were selected from the material studied by Larsen and Drooger. For each species, three specimens were picked for each depth, all with diameters in the range $850-1357 \mu \mathrm{m}$ (table 1).

The mean values of lamellar thickness from the umbilical regions of the umbilical and spiral sides respectively are shown in fig. 1 and 2 . In the sections thickness of both the primary chamber walls and the secondary lamellae increased during ontogeny (figs. 3, 4). In addition, some variation occurred in the thickness of single laminae, hence, average lamel thickness is recorded.

\section{Discussion}

From the results presented above, it is evident that all three species investigated show a tenden-

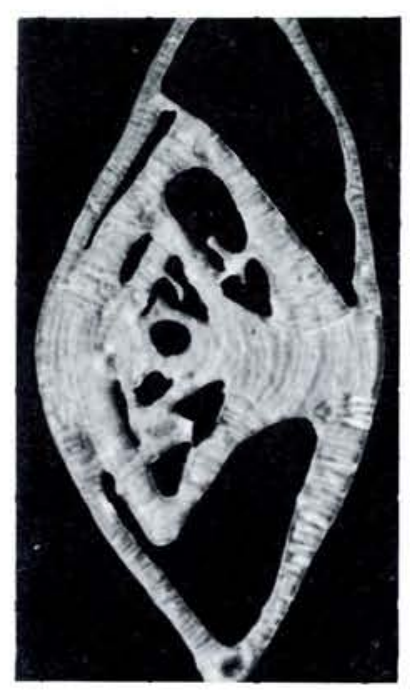

Figure 3. Polished and etched vertical section through the proloculus of A. lessonii. $70 x$. 


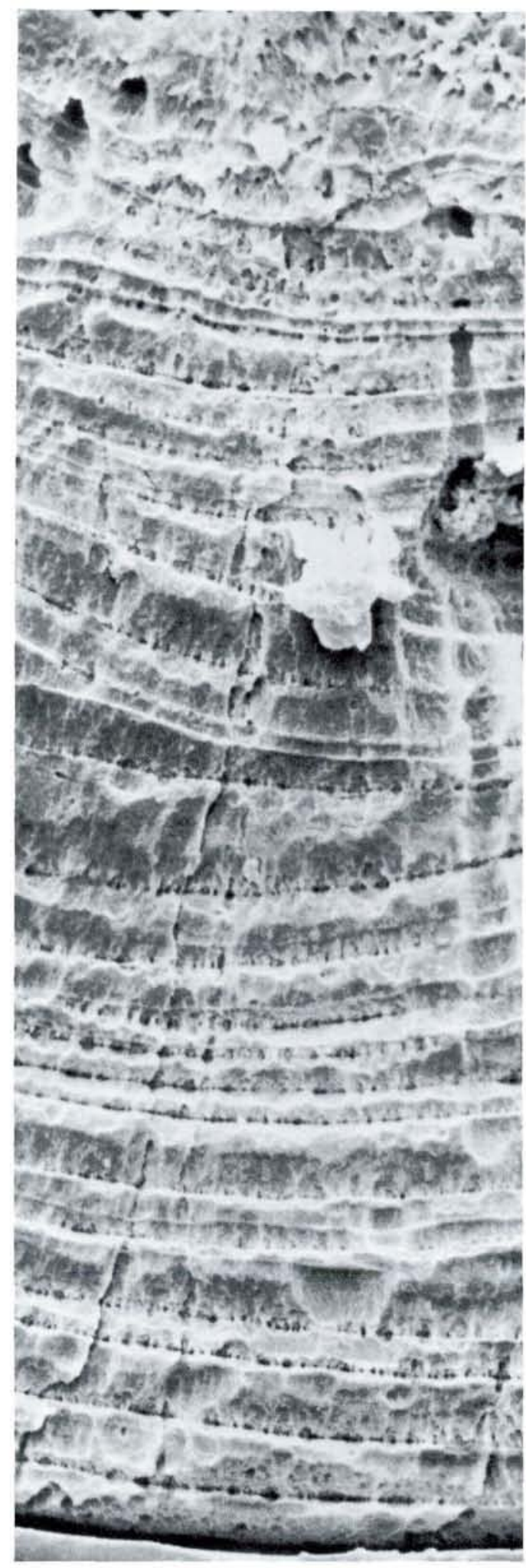

cy towards reduction in thickness of the secondary laminae with depth. The magnitude of the thickness reduction is quantitatively sufficient to account for the changes in test shape observed by Larsen and Drooger (1977).

And, just as the phenotypic variability demonstrates a change in test shape within the single species, a general genotypic trend with depth is also evident in the species of Amphistegina studied (fig. 5). This interspecific trend with depth is evident both with regard to lamellar thickness and to the resultant test shape (surface to volume relationship).

Hallock (in prep) found that, on a western $\mathrm{Pa}$ cific reef, $A$. lessonii produced about $0.2 \mathrm{mg}$ carbonate per individual while $A$. lobifera produced about $0.5 \mathrm{mg}$ per individual. Both species grew to maturity in approximately the same length of time, though $A$. lobifera attained larger overall size, both shell diameter and shell thickness. The differences in both size and carbonate productivity per individual are easily understood in light of the lamellar thickness differences between the two species.

Also using Amphistegina from the Gulf of Elat, Hansen and Buchardt (1977) and Buchardt and Hansen (1977) demonstrated a gradual reduction in ${ }^{18} \mathrm{O}$ depletion with depth. This depletion was suggested to be intimately connected with the decreasing amounts of light and thereby smaller amounts of fractionation by symbiont activity agreeing well with a recent study by Erez (1978). These authors also showed that at the lower limits of existence of symbiont-bearing Amphisterina (120 $\mathrm{m}$ in Elat), the deeper dwelling species approach the ${ }^{18} \mathrm{O}$ depletion values as found in non-symbiont carrying Bolivina spp.

It seems that the shallow dwelling forms $(A$. lobifera and $A$. lessonii) have higher requirements for symbiont activity than the two deeper dwelling forms (A. papillosa and A. bicirculata). The two latter forms apparently can exist at very low symbiont activity levels near their maximum depths of occurrence since, in accordance with the oxygen isotope values, their skeletal carbonate production is almost unaffected by symbiotic fractionation.

Since carbonate production is enhanced by

Figure 4. Detail of Fig. 3 showing the secondary lamellae of the spiral side. The pitted lines represent lamel boundaries. $1265 x$. 


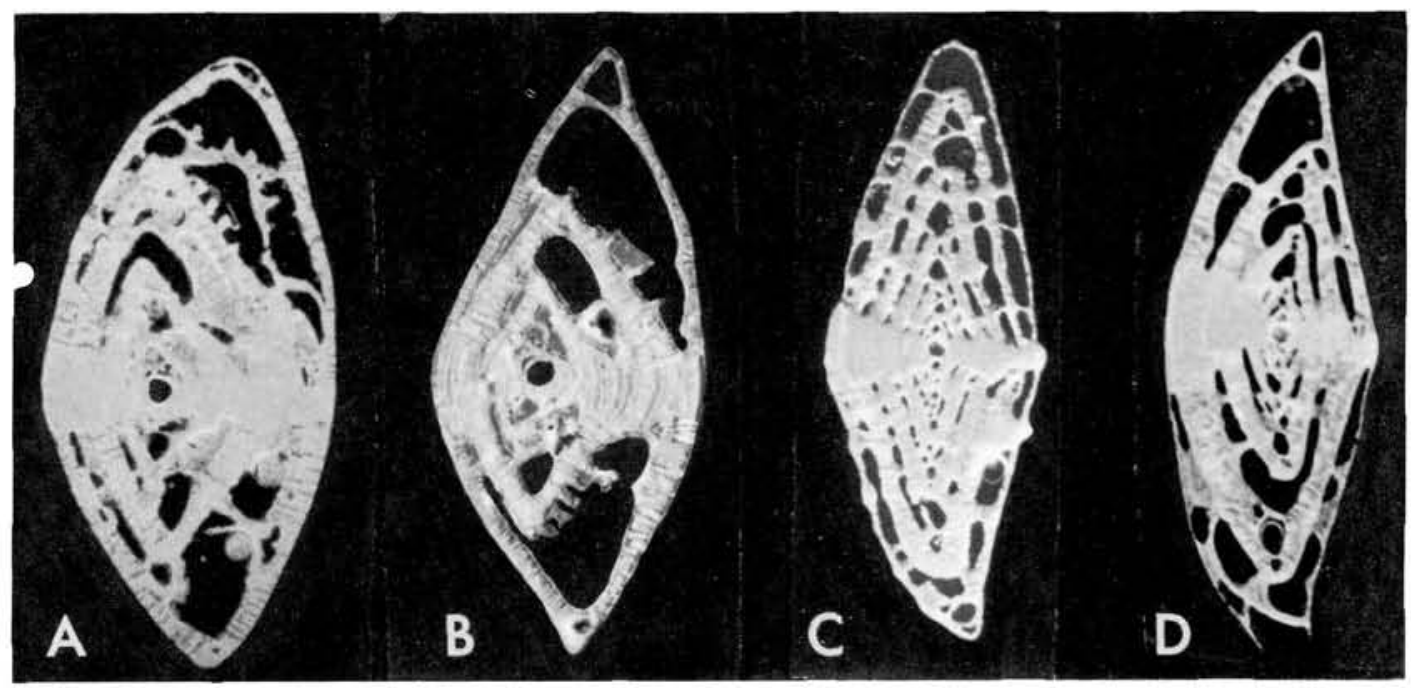

Figure 5, Vertical sections of A. lobifera $(A), 48 \times x ;$; lessonii (B), $53 x$; A. papillosa (C), $63 x$; A. bicirculata (D), $44 x$.

symbiotic activity in a number of marine invertebrates (Pearse and Muscatine, 1971), it is not surprising that decreased symbiont activity in Amphistegina with increased depth as demonstrated by the oxygen isotope values is at the same time manifested in decreased thickness of the lamellae and thereby in the reduced amount of carbonate secreted at each chamber-forming instar.

Variation in lamellar thickness as related to depth of occurrence is a potential tool for paleobathymetric interpretation. It would appear to be a more refined indicator of relative depth of habitat within the photic zone than gross morphology per se.

Acknowledgements. P. Hallock's stay at the University of Copenhagen was supported by a grant (no. 511-8682) from the Danish Natural Science Research Council.

Laboratory assistants J. Fuglsang Nielsen and S. Hansen provided greatly appreciated help in the SEM and photographic work.

$\mathrm{H}$. Egelund drew the figures.

Drs. Z. Reiss (Jerusalem), C. W. Drooger (Utrecht), and especially A. R. Larsen (Copenhagen) kindly read the manuscript and offered valuable suggestions.

The Geological Institute, University of Copenhagen, is thanked for permission to use the facilities and collection of the Micropaleontological Laboratory and the equipment of the Laboratory of Electron Microscopy.

The study is part of the joint $\gg$ Micropaleontology, Ecology and Paleoecology Programme $\alpha$ in the Gulf of Elat coordinated by Prof. Z. Reiss, The Hebrew University, Jerusalem.

\section{Dansk Sammendrag}

Endringer i skalform med dybde hos tre arter af foraminiferslægten Amphistegina fra Elat Bugten, Israel kan kvantitativt forklares ved en tilsvarende udvikling af de sekundære lameller i skallerne.

\section{References}

Buchardt, B. and Hansen, H. J. 1977: Oxygen isotope fractionation and algal symbiosis in benthic foraminifera from the Gulf of Elat, Israel. Bull. geol. Soc. Denmark, 26: 185-194.

Erez, J. 1978: Vital effect on stable-isotope composition seen in foraminifera and coral skeletons. Nature, 273, 199-202.

Hansen, H. J., Reiss, Z, and Schneidermann, N. 1969: Ultramicrostructure of bilamellar walls in foraminiferida. Rev, Españ. Micropal. 1: 293-316.

Hansen, H. J. and Reiss, Z. 1972: Scanning electron microscopy of some Asterigerinid foraminiferida. J. Foram. Res. 2: 191 199.

Hansen, H. J. and Lykke-Andersen, A.-L. 1976: Wall structure and classification of fossil and recent elphidiid and nonionid foraminifera. Fossils and Strata 10: 1-37.

Hansen, H. J. and Buchardt, B. 1977: Depth distribution of Amphistegina in the Gulf of Elat. Utrecht Micropal. Bull. 15: 205-224.

Hottinger, L. 1977: Distribution of larger Peneroplidae, Borelis and Nummulitidae in the Gulf of Elat, Red Sea. Utrecht Micropal. Bull. 15: 35-110.

Hottinger, L. and Dreher, D. 1974: Differentiation of protoplasm in Nummulitidae (Foraminifera) from Elat, Red Sea. Mar. Biol., 25: 41-61.

Klinker, J., Reiss, Z., Kropach, C., Levanon, I., Harpaz, H. and Halicz, E. 1976: Observations on the circulation pattern in the Gulf of Elat (Aquaba). Israel J. Earth-Sci. 25: 85-103. 
Larsen, A. R. 1976: Studies of recent Amphistegina, taxonomy and some ecological aspects. Israel Journ. Earth-Sci., 25: $1-26$.

Larsen, A. R. and Drooger, C. W. 1977: Relative thickness of the test in the Amphistegina species of the Gulf of Elat. Utrecht Micropal. Bull., 15: 225-240.

Pearse, V. B. and Muscatine, L. 1971: Role of symbiotic algae (zooxanthallae) in coral calcification. Biol. Bull. Mar. Biol. Lab. Woods Hole, 141: 350-363. 